\section{Wykorzystanie elementów kultury regionalnej w architekturze na przykładzie Zakopanego. Wprowadzenie Parku Kulturowego w przestrzeni ulicy Krupówki}

The use of regional elements in architecture by the example of Zakopane, Poland. Implementation of Culture Park in the streetscape of Krupówki

\section{Streszczenie}

Romantyzm i fascynacia górami zapoczatkowała popularność Zakopanego, jako ośrodka turystycznego Kultura Podhal jego architektura i sztuka użytkowa stały się rozpoznawalnymi symbolami regionu, stanowiąc o niezwykłej skali zainteresowania Zakopanem i wpływając na jego rozwój urbanistyczny. Wizytówkowa ulica miasta, Krupówki, w przeszłości pełniąca się wielkoformatowe reklamy, punkty handlu z ręki do ręki, szyldy i plakaty oraz elementy matej architektury, często o niskie wartości estetycznej i zupełnie niezwiązanych z estetyką otocznia urbanistycznego. Po fali krytyki tego stanu rzeczy, która przetoczyła się przez media, w roku 2016 miasto wprowadziło obszar Parku Kulturowego dla Krupówek i przylegających ulic, którego głównym zadaniem jest ochrona lokalnych wartości regionalnych, a także poprawa jakości przestrzennej głównej ulicy Zakopanego. Celem artykułu jest identyfikacja i analiza typowych elementow architektury regionalnej Krupowek oraz przygotowanie wytycznych dla dalszej ochrony regionalnych wartości architektonicznych. Artykuł prezentuje także rezultaty przekształceń przestrzeni ulicy zgodnie z wytycznymi opracowanymi dla Parku Kulturowego.

Abstrakt

Romanticism and fascination with the mountains opened Zakopane to tourism. Its culture, folk art vernacular architecture became symbols of the region, making Zakopane highly popular and impacted its urban development. The most importan facades covered with advertisements that disfigured the streetscape. Billboards, posters, information boards, hand-to-han sales, unlicensed street shows, and street - displayed goods were besieging the space and were in most cases not related to the regional culture. After the critique and nationwide media discussion local authorities in July 2016 initiated Culture Park, mainly to protect regional values and to better the overall image of the street.

The aim of this paper is to identify and classify typical forms of regional elements of Krupówki street to formulate and prepare guidelines for the preservation of regional heritage. The paper will also present the transitions of the streetscape caused by Culture Park.

Stowa kluczowe: ochrona dziedzictwa kut

\section{WSTĘP}

Ulica Krupówki jest główną ulicą o charakterze handlowym w Zakopanem. Od czasów zmian systemowych w latach 90. do momentu wprowadzenia Parku Kulturowego nie podlegała ona żadnym regulacjom w zakresie ochrony estetyki. $W$ rezultacie, $w$ ciągu ulicy powstały liczne dobudówki mieszczące punkty handlu. Murowane elewacje licowano deskami przypominającymi chaty góralskie. Wprowadzano nadmierne zdobienia elewacji. Wielkoformatowe reklamy pokrywające reklamowe. Stworzyły one chaos uniemożliwiający odbió ulicy Krupówki jako estetycznej. Także wartości regionalne obecne zarówno w Zakopanem, jak i na Krupówkach uległy degradacji lub nadinterpretacji.

Niechlubne nagłówki prasowe nazywające ulice Polskim Las Vegas (Kraczyńska, 2011) oraz inicjatywa społeczności za kopiańskiej zaowocowały pracami lokalnego Urzedu Miasta napiansarkiem Kulturowym. Jego wprowadzenie w 2016, choc poczatkowo spotka sie z protami lokach kuie coraz wieksze grono zwolenników. Pierwsze rezultaty ikp coraz wieksze ge z proster

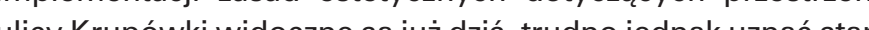
la w kierunku poprawy estetyki i właściwego uwypuklenia wartości regionalnych.

\section{ZAKOPANE: HISTORIA I ROZWÓJ MIASTA}

Zakopane jest popularna miejscowościa turystyczno-wypoczynkową określaną mianem zimowej stolicy Polski. Ta nazwa jest poniekąd prawdziwa, gdyż rocznie miasto odwiedzan jest przez ponad 3 miliony turystów. Usytuowanie, w poblizu Tatr, najwyższego pasma Karpat na wysokości około 740 mnpm, do 1000 metrow w Kuznicach. Miasto zajmuje powierzchnię około 8486 hektarow i liczy 27000 mieszkańców. Początki Zakopanego sięgają drugiej połowy XVI w. Niesprzyjający klimat, ciężkie i długie zimy, lasy, trudne uksztaltowanie terenu oraz mało urodzajna ziemia nie sprzyjały procesom osadniczym. Pierwszy raz, pod nazwą Nowa Osada, wymienione zostało w 1624 roku (Mantyka, Momot 2003). Hale tatrzańskie służyły pasterzom jedynie w miesiącach letnich. Sytuacje zmieniło odkrycie złóż srebra, złota, miedzi oraz żelaza w Tatrach i wybudowanie pieców hutniczych w Kuźnicach (1766) oraz w pobliskim Kościelisku (1767).

Fascynacja górami i chęć ich odkrywania stała sie gtówn przyczyna przyjazdu pierwszych turystów. Zakopane zaczéto prozwijó sie dwutorowo- jako ośrodek hutniczy (rejony Kuznic) oraz turystyczny (Zakopane). W 1818 roku osada liczyla 1805 mieszkańców.

W wyniku pierwszego rozbioru Polski w 1772 roku Zakopan zostało wcielone do Imperium monarchii Habsburgów. A obszar Tatr stał się własnością cesarstwa. Dobra kuźnickie przejeła rodzina Jana Wincenta Homolacsa. Kolejnymi właścicielami Zakopanego byli: Ludwik Eichborn (1869-1879), Magnus Pelz (1879-1888), Jakub Goltfinger (1889). Dnia 9 maja 1889 dobra zakopiańskie kupił Władysław Zamoyski, który w późniejszym czasie stał się patronem wielu inicjatyw na obszarze Zakopanego. Wioska stała się celem wypraw naukowych i turystycznych nie tylko Polaków, ale także Niemców, Austriaków czy Węgrów. Organizacje społeczne jak np. Towarzystwo Tatrzanskie, ktore powstało w 1873 roku zaczęło wyznaczanie i budowę szlaków gorskich, schronisk, czy tez budowę zlokalizowanego przy ulicy Krupówki Dworca Tatrzanskiego- budynku użyteczności publicznej z salą koncertową, biblioteka i czytelnią. To samo Towarzystwo ufundowało budynek Szkotę Snycerską, przyczyniając się do popularyzacji regionalnej ture. Billboards, posters, information boards were covering the majority of the street. Also regiona values were degraded and over-interpreted.

The national press referred to Krupówki Street as "Las Vegas". (Kraczyńska 2011)

As a result of inhabitants and local government initiative Krupówki Street and its neighbourhood have been protected with the status of the Culture Park since the $1^{\text {st }}$ of July. Even though some locals and business owners were protesting against the new regulations for the visual identity the plan is after the implementation of new rul The changes ons are obvious, but it is hardly the satisfactory state: further spatial transformation of Krupówk Street is needed, putting the strong emphasis on the local regional values.

2. ZAKOPANE: HISTORY AND ITS DEVELOPMENT Zakopane is widely known as the winter capita Situated at the foot of the Tatras, it has an altitude between 740 to 1000 (the area of Kuźnice) meters above the sea level, an area of 8486 hectares and a population of approximately 27000 habitants. The Settlement of Zakopane was relatively late and took place in the second half of the sixteenth century, largely due to the capricious climate, long vielding soils. It was first recorded in 1624 as Now Osada (New Settlement) (Mantyka, Momot 2003). It was firstly used only during summer months by shepherds and later, following the exploration and discovery of minerals in the Tatras, it became associated with mining and forging - 1766 a forge was built in the nearby village of Kusnice and in 1767 nother one in the village of Koscielisko.

Tirst tourists to the Tatra foothils $Z$ akought was developing two-way: on one hand steel industry, which was mainly concentrated in Kuźnice and on the other tourism, which gradually gained in importance and helped to develop the nearbylocated Zakopane settlement. In 1818 the village had a population of 1805 people.

Paw the whole tain area was then controlled directly by the State. Property ownership in Kuźnice and the surround ing area also changed, the most important being Jan Wincent Homolacsa, Ludwik Eichborn (18691879), Magnus Pelz (1879-1888), Jakub Goltfinger (1889). Ownership of he Zakopane estate changed Wain on $9^{\text {th }}$ of May 1889 with its purchase by Count who later became the benefactor of many initia tives around the area.

A growing number of scientists and tourists mainly from Poland, Austria, Hungary and Germany also began to populate Podhale region.

Many organizations, societies and association were very important for the village development. (Tatra Society), established in 1873. It organsized mountain routes and mountain hostels. It was also responsible for building the Dworzec Tatrzan- 
wienie chat z elewacją z otworami okiennymi i drzwiowymi na godzine 11 , czyli od poludnia), umieszzenie budynkow gospodarczych chroniace chałupy mieszkalne przed przeważającym południowo- zachodnim kierunkiem wiatrów. Kat i konstrukcja dachu, okapy, małe otwory okienne i drzwiowe miały służyć ochronie człowieka przed otaczającymi, ciężkimi warunkami atmosferycznymi. Użyte grube płazy miały chronić budynek przed stratami cieplnymi. Brak komina utrzymywał się na terenie Podhala do końca XIX wieku.

szczeń w typowej chałupie góraciej czarnej i biatej czarnej i białej izby

Nawet tutaj jasno zauważyć można ekonomiczne wykorzystanie ciepła- izba czarna, ogrzewana piecem, była miejscem, gdzie toczyło się życie rodzinne. Tutaj gotowano, spożywano posiłki. Izba służyła jednocześnie za sypialnie, często z małymi zwierzetami. Biała izba pełniła $z$ kolei reprezentacyina rolę. To właśnie tutaj przyjmowano ważniejszych gości, przechoiejsze dobra materialne.

Początkowo przedmioty użytkowe nie były dekorowane, jednak w późniejszym czasie górale, wprawni snycerze rzeźbil nawet najmniejsze obiekty sztuki użytkowej, a także elementy architektoniczne. I tak do najważniejszych ornamentów charakterystycznych dla budownictwa regionalnego należy sosręb $z$ wyrzeźbiona data wybudowania budynku, imieniem i nazwiskiem właściciela i elementami zdobniczymi takimi jak rozeta, symbol życia, religijne cytaty wraz z motywami roślinnym i geometrycznymi. Innymi zdobionymi elementami architektury były pazdury, tragarze, odrzwia z psami i nadproża okienne.

3.2. Narodziny i rozwój stylu zakopiańskiego

Wybudowanie połącenia kolejowego pomiędzy Krakowem a Chabówką w 1884, działalność Towarzystwa Tatrzańskiego zaowocowało zwiekszoną liczba turystów. Jednotraktowe, a później takie dwutraktowe jące, aby sprostać wzrastajace

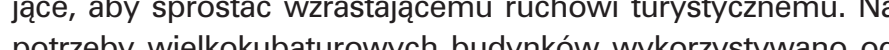
pońca XIX tzw. styl szw loggiami, werandam loggiami, we da mi, tarasami i calkonami sluzacymi do kapieli stonecznych, a także eklektycznymi wzorami geometrycznym

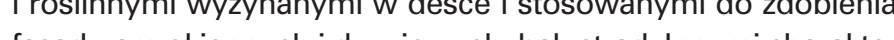
fasad, ram okiennych idrzwiowych, balustrad. Innymi char rystycznymi elementami byly zdobione kratownice i łuki.

Jednak styl ten, w porownaniu do architektury regionalnej, nie pasował do Zakopanego, silnie kontrastując $z$ jej prostymi formami, jednoczesnie czyniąc je identycznymi do innych miejscowości o charaktze turystyczno-wypoczynkowym takich tak jak Krynica czy Szczawnica w Polsce lub Stary Smokowiec na Słowacji.

Przybycie Stanisława Witkiewicza do Zakopanego w 1886 dało początek staraniom o utworzenie stylu zwanego $w$ późniejszym okresie stylem zakopiańskim.

Witkiewicz zafascynował się lokalną sztuką użytkową i architekturą, którą uważał za „już nie surowy materiał, ale dość wyrobiony styl, z którego mogłoby się rozwinąć samodzielne i nowe budownictwo" (Jabłońska, 2008). prevailing southwest winds. Houses were mainly built on a rectangular plan layout. The longer eevation had the door and windows placed in the 11 o'clock position requiring the houses to face south. The most popular one-line house design could be characterized by the presence of

The black chamber (room with an open fire without a chimney) the closest to the sheds for the convenience of tending animals, was the place where family life took place. It served both as a kitchen ing stove During the winter the wh waty even some small animals lived there. The main purpose of the white chamber and the living room was representational. These rooms were beautifully decorated with the living room used to entertain notable guests, as well as to keep the mos expensive and precious possessions.

The early highlander house typically had no decoto decorate even for the smallest of everyday objects. This eventually found its way into the vernacular architecture. The most important elemen of the decorative motifs was the sosręb (crossbeam) running from the east to the west wall. was a central part of the black and white chambers and had both structural and ornamental purposes. The the owner and the year the building was ere ed, and various decorative elements such as the rosette - which depicted the symbol of life, a star and religious quotes together with floral and geometrical motifs. Other often decorated elements were: windows and doors, solutions of gables, roof ridge decorative pins (pazdury) etc.

3.2.The birth and development of Zakopane style As a result of the newly opened railway connection As ity of the Tatra Society (Towarzystwo Tatrzańskie Zakopane continued to grow. This required furthe development of the village and forced the evoluone - line to two accommodate growing number of visitors. The Swiss style became popular in large cub ture buildings by the end of XIX c. Characterized by a use of asymmetrical porches, bay windows, verandas and balconies, it included decorative wooden panels with eclectic motifs of foreign folk cic were and historical citations. Other characterisThe Swiss style compared with the vernacular apear similar to other summer resorts in the Tatras such as Smokovec in Slovakia, Krynica and Szczawnica in Poland.

The arrival of Stanistaw Witkiewicz in 1886 marked the beginning of the fight for the "Zakopane style",
Witkiewicz described the regional approach to architecture as 'not just 'a raw material anymore, but were [now] presented in quite a refined style, from which a new and independent architecture
Jednocześnie, z powodów politycznych, Stanisław Witkiewicz i architekturze w oparciu właśnie o rodzima architektura regionalną. Pierwszym budynkiem zaprojektowanym przez Witkiewicza i wybudowanym w nowym stylu przy użyciu tradycyjnych materiałów i konstrukcji oraz z zastosowaniem nieco bardziej rozbudowanej ornamentyki była Willa Koliba przy ulicy Kościeliskiej (ukończona w 1892 roku). Skala budynku była o wiele wieksza, niz w przypadku chałup regionalnych przypomin budyki w stylu szwajcarkim. Ten pinyc przypoming budy $z$ wykorzystaniem regionalnego sen pierwszy duży sukces i w krótkim czasie powsta równ sty in odniós dy d za 1895, Zofiówka 1895)

W swoich projektach Witkiewicz przekształcit inne elementy tradycjonalnej chaty góralskiej, takie jak np. podmurówka, pazdury czy tez sosręb, który stracił swoją konstrukcyjną rolę. Innymi elementami dodanymi do budynku były werandy, balkony, ozdobne kominy, okna o rożnych kształtach. Także wnętrza o elementy sztuki użytkowej inspirowane były lokalną kulturą. Najbardziej reprezentacyjnymi budynkami wybudowanym w stylu zakopiańskim stały się Willa pod Jedlami (1897) oraz Kaplica Najświętszego Serca Jezusa na Jaszczurówce (1904-1907). Mimo zamierzeń Witkiewicza styl zakopiański nie rozprzestrzenit się w Polsce. Nie udała się również transformacja stylu $\mathrm{n}$ architekturę murowaną. Jednak rola St. Witkiewicza w konserwacji i popularyzacjl architektury regionalnej oraz przekształceniu i dostosowaniu jej do wymogów czasu była nieoceniona.

\section{ROZWOJ PRZESTRZENNY ULICY KRUPÓWKI OD 80 LAT} XIX DO WSPOKCZESNOSCI.

Zakopane kojarzone jest z górami, kulturą regionalną, ale także z ulica Krupówki, która stanowi wizytówke miasta, podobnie jak inne ważne ulice polskich miast takie jak Krakowskie nie jak inz waz Worszawie, Floriańska w Krakowie czy Piotrkowska w Łodzi.

Ulica Krupówki o długości 1100 metrów, zlokalizowana jest pomich Kierwotnie wy XVII w. Ulica pas

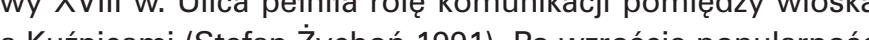
Zakopanego, na poczaku XVII Wieku, Krupowk radyka Zakopanego, na początku XVII wieku, Krupówki radykalnie zmieniły charakter i dominującą zabudową stały się obiekty wzniesione w stylu szwajcarskim np. gmach Dworca Tatrzanskiego, czy mieszcząca się w sąsiedztwie Szkola Snycerska. Po uzyskaniu stausu Stacji Klmatycznej, Krupówki, a w szcze gólności ich dolna i środkowa cześć, dzięki nowej zabudowi zmieniły charakter z wiejskiego, na miejski. To właśnie tuta budowano hotele, pensjonaty oraz obiekty handlowe, co kontrastowało z górną częścią ulicy luźno zabudowaną prywatnymi willami. Wiele $z$ tych realizacji zbudowano $w$ drewnie, be konkretnych cech stylowych.

Kolejnym wydarzeniem, które przyniosło radyklane zmiany w architekturze Krupówek był pożar w 1899 roku, który zniszczył 16 budynków, zastąpionych potem eklektycznymi, murowanymi konstrukcjam could develop'.(Jabłonska, 2008) In fact, Witkiewicz wanted to develop this idea into an original national style of art and architecture.

The first building designed by Witkiewicz in Zakoer Zygmunt Gnatowski) on Kościeleliska Street (Fig $1 c$ and $1 \mathrm{~d})$. It used traditional materials and the form of construction and ornamentation of the Highlander house, with many eclectic citations. The scale of the building was much larger, being similar to a typical wo-storey Swiss style villa. This first experiment was very successful and soon other projects follow: sza (1895), Zofí́wka (1895) among otha (1894), OK Witkiewicz experimented with more elements of vernacular style like stone wall base, multiple roof ridge decorative pins (pazdury) and the sosręb or crossbeam, which eventually lost its construction function. The most representational buildings of the style were arguably the Willa pod Jedlami (The House under the Firms) erected in 1897 and the Chapel of the Sacred

列 tion to the brick was unsuccessful. Nevertheless, Stanisław Witkiewicz played an important role in preservation and popularization of the Podhale veracular architecture.

4. THE SPATIAL DEVELOPMENT OF KRUPÓWKI PRESENT

Zakopane is strongly identified with the mountains, regional culture and with Krupówki Street, which is the highlight of the city, among other famous polish streets like Krakowskie Przedmiescie in Warszawa Horiansska in Krakow and Piotrkowska in todz. Krupówki Street, only 1100 meters long, is located Zamoyskiego Street. It is named after the glade that previously existed. It was first used to herd animals and from the second half of the $18^{\text {th }}$ century as a communication between the Kuźnice forge and the village. (Stanistaw Żychon 1991). Until Zakopane gained its popularity, buildings along the path were in the early 18 th century German architects beg a trend where Swiss - style wooden villas began the most popular style. The main buildings in this style around Krupowki Street were "Dworzec Tatrzański" (1881-1882) and the Woodcarving School (1882-1883) (Józef Tarnowski 2012). Further development in this period was connected with the "Climate Station" title received in 1886. BeWheen 1876 and 1892 the middle and the bottom city look - hotels, pensions and commercial buildings were situated in this part of the street, which contrasted sharply with the private villas and smaller scaled buildings in the upper part of the street. The next change to Zakopane's architecture was a result of fire in 1899. Overall 16 buildings were destroyed around Krupówki Street that saw the Eclectic style. The organization of FIS competition in 1929
and again in 1939 brought a lot of changes in 
Organizacja zawodów FIS (w latach 1929, 1939) przyniosła kolejne ozywienie $w$ budownictwie miasta. Krupowki połaczone zostają z nowo wyznaczona ulicą Piłsudskiego i skocznią narciarska. Historyczny styl dominuje w architekturze centrum Zakopanego, konkurując z zabudową modernistyczna i funkcjonalizmem

Wybuch II Wojny Światowej zahamował rozwój miasta. Do najważniejszych zmian przestrzennych przeprowadzonych w tamtym okresie w Getości). W tym okresie wybudowano tylko czlery wiepodleglosil). W tyz wybudowien obiekty, m. Giewont). Archiektura reallzowana w tym okresie była kom-

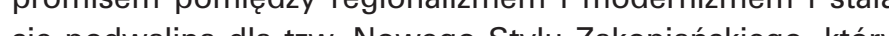
się podwaliną dla $z$ w. Nowego Stylu Zakopianskiego, ktory wykorzystywal drowno i elementy kamienne oraz formy socreallstyczne. Przykladem jego zastosowania moga być wybudowany w tym "Dom Turysty" (Żychon 1977). W okresie transformacji, w początkach lat $90 \mathrm{XX}$ w. Krupówki uzyskuja nowy wygla d dzeck zmia małej architektury. Pochyłe latarnie wzdłuż ulicy początkowo uznano za elementy dość kontrowersyjne, jednak w chwili obecnej stanowią znak rozpoznawczy miasta.

Wieloletni brak planu zagospodarowania przestrzennego spowodował chaotyczny rozrost zabudowy ulicy. Budynki często są przeskalowane, a zabudowa jest zbyt gęsta. Nie były to jedyne negatywne zjawiskiem kształtującym wygląd ulicy. Począwszy od lat 90 XX ulica bardzo zmienifa swój charakter i funkcję. Powoli, deptak miejski z eleganckimi hotelami oraz zabudową mieszkaniową przekształcił się w ulice handlową. Tę zmianę odzwierciedlała wręcz przytłaczająca ilość reklam. Banery eksponowane były nawet na całych elewacjach budynku, zasłaniając oryginalne fasady. Kolejnym elementami wprowadzajacymi wizualny chaos były nieestetycznie, przeskalowanie szyldy sklepowe oraz krzykliwe tablice reklamowe czesto dublowane, tak aby widyczne były pod różny katami. Dodatkowo, oprócz nazwy lokalu lub ustugi bardzo cze, czi. Dodu W wielu wypadkch zatrocontow. W wiel wypacio prze-

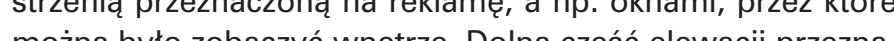
można by zobaczý wa rêtze. Dolna czesć elewaji przezna-

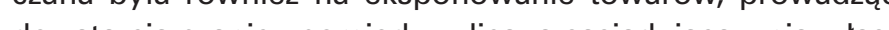
do zatarcia granicy pomeęzy ulica, a sąsiadująca z nia wlasnością prywatną. Takze niska zabudowa drewhiana o charakterze regionalnym stala się oflarą wszechobecnych reklam. Ze względu na wysokie ceny powierzchni usługowej na Krupowkach sprzedaż miesclia się w nawet w prowizorycznych dobudowkach czy tez bramach prowadzących do kamienic. Zaczęto wykorzystywac elementy kultury regionalnej, by zachęcić turystów do odwiedzenia sklepow i punktów gastronomicznych. Bardzo często pojawiającym się motywem było licowanie murowanej elewacji drewnem, tak aby stworzyc wrażenie wejścia do chaty regionalnej. Elementy budynków dekorowano motywami góralskimi, nawet wówczas, gdy nie pasowały one do stylu architektonicznego.

Także powstająca nowa architektura nie ustrzegła się płytkich zapożyczen i nieudanych prób manifestacji kultury regional- the cityscape. Krupówki was connected with Pilsudskiego and the ski jump. Historical style is

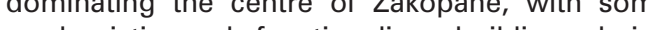
modernistic and functi

The city. The the route to Gubatónka funicular was cleared

and a new square (today's Plac Niepodlegtości) was built. Only four new buildings constructed, notably the Deutsches Heim (later Giewont Hotel). The architectural style during the war was a comcame an important influence in shaping the $\mathrm{New}$ Zakopane style.

After the war high levels of wood and stone crafts and social realist forms, which continued throughout the interwar period, characterized the architecture. Some mountain hostels and the "Dom Turysty" are the examples of buildings in "the New "Zling 1990s, Krupówki changed their look the early modernization of pavement and architectural elements. The tilted lampposts, for example, were highly controversial, nowadays became the symbol of the city.

The lack of a Spatial Development Plan lead to chaotic development - buildings were out of scale an the architecture too dense. It wasn't the only neg Since the 1990s the street had chas

acter and function - beforehand the elegen its charwith hotels and residential buildings transforme into commercial street. This change was reflected in the overwhelming amount of advertisement. Billboards, posters, information boards were covering the entire street. In many cases there boards were another factor in creating the visua chaos - there were too big, doubled, so they could be seen under a different angle. The typefaces and colour schemes were aggressive and not very aesthetically pleasing. Some of the places were displaying big photographs of the products they were selling. The bottom parts of the facades and play making it impossible to differentised as a disthe private and public space of a street. Due to high rental prices many shops were placed in the provisional extensions added to the existing buildings.

Also regional values were degraded and over-interpreted to attract the tourists do visit the shop and restaurants. To achieve the effect of a regionconsisting of wooden planks on brick walls to create the imitation of an entrance to a traditiona farmstead. Elements of local architecture were used to decorate the buildings, even though stylistically they differ.

Also, the newly constructed architecture didn't stay away from unnecessary citations and manifestatation of oscypek, local sheep cheese on the glass façade of a large scale commercial building withou any other elements of vernacular architecture.
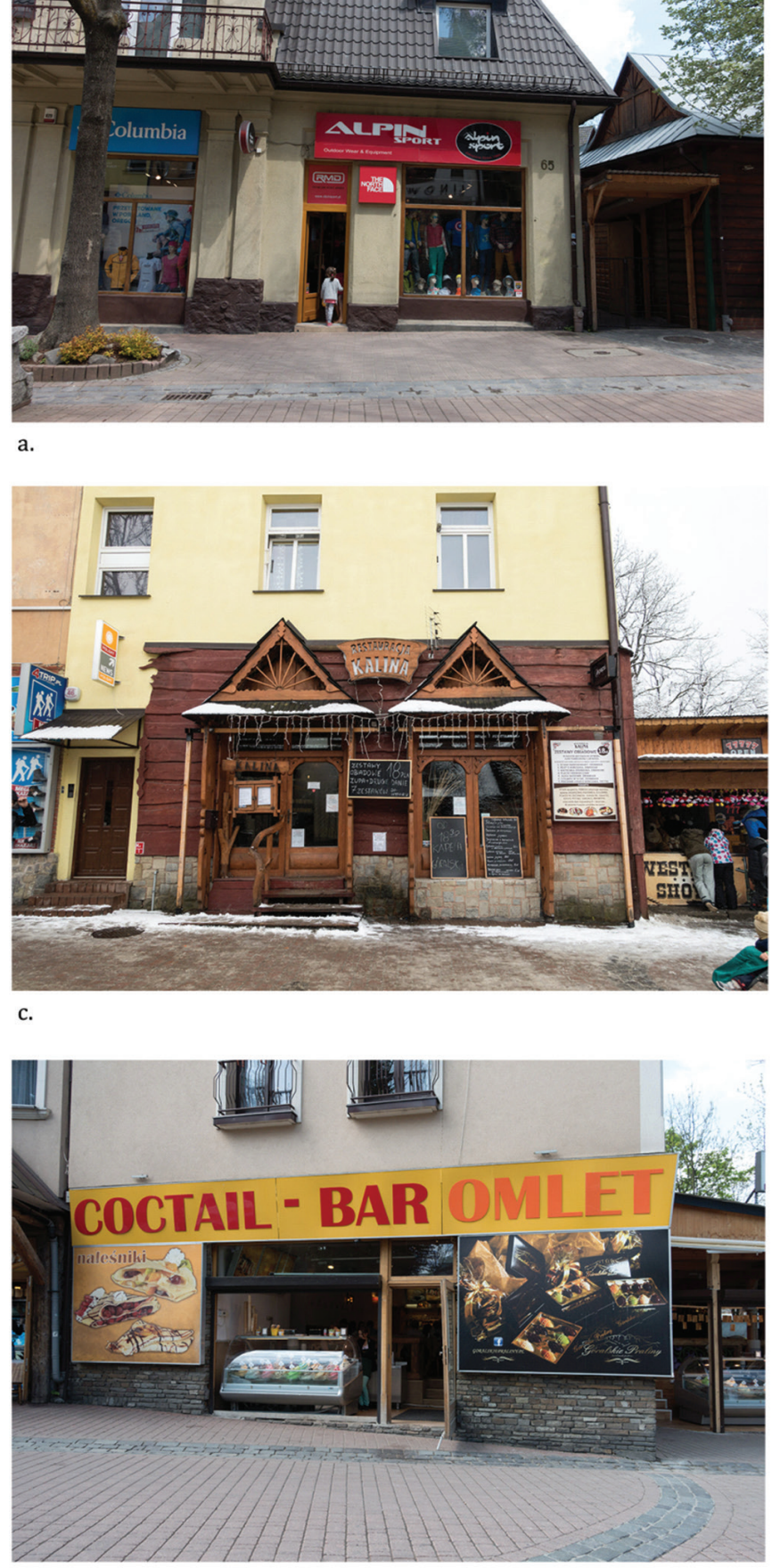

11. 2. Pozytywne zmiany, które zawszy w wyniku wprowadzenia uchwały o Parku Kulturowym. Zdjęcia a,c, e - wykonane w czerwcu 2016 roku. Zdjeccia b, d,f - wykonano w maju 2018 roku. . djecia wiasne
III. 2. Positive changes, due to the Culture Park regulations. Pictures a,c, e - taken in 2016. Pictures b,d, f $f$ taken in May 2018. Source: Own Study

nej, np. wielkokubaturowa galeria centrum nawiązuje forma do kształtu oscypka - w projekcie brak innych cech architektury regionalnej.

5. IDEA PARKU KULTUROWEGO KRUPÓWKI I PROCES JEJ WDRAŻANIA

Koncepcja Park Kulturowego pojawiła się w Polsce jako sposób na ochronę wartości kulturowych lub historycznych za pomocą narzędzi prawnych dostępnych na poziomie lokalnym. Aby zatrzymac ekspansję reklam, opanować chaos wizualn ukierunkować dalsze przemiany krajobrazu głównej ulicy Zakopanego, Urząd Miasta stworzył plan ochrony ulicy Krupówek i przylegających terenów. Uchwała weszła w życie 1 lipca

\section{THE IDEA OF CULTURE PARK AND ITS} IMPLEMENTATION

The concept of Culture Park was introduced in Poland as a way of protecting cultural and historic

To stop the expansion of the commercials, get the visual chaos under control and to direct the future changes of the main street of Zakopane, he city hall created the Krupówki protectio plan. The act entered into the force on the $1^{\text {st }}$

Wrules and protection procedures incorporated commercial and other services in the public and improve the aesthetic quality of the building 

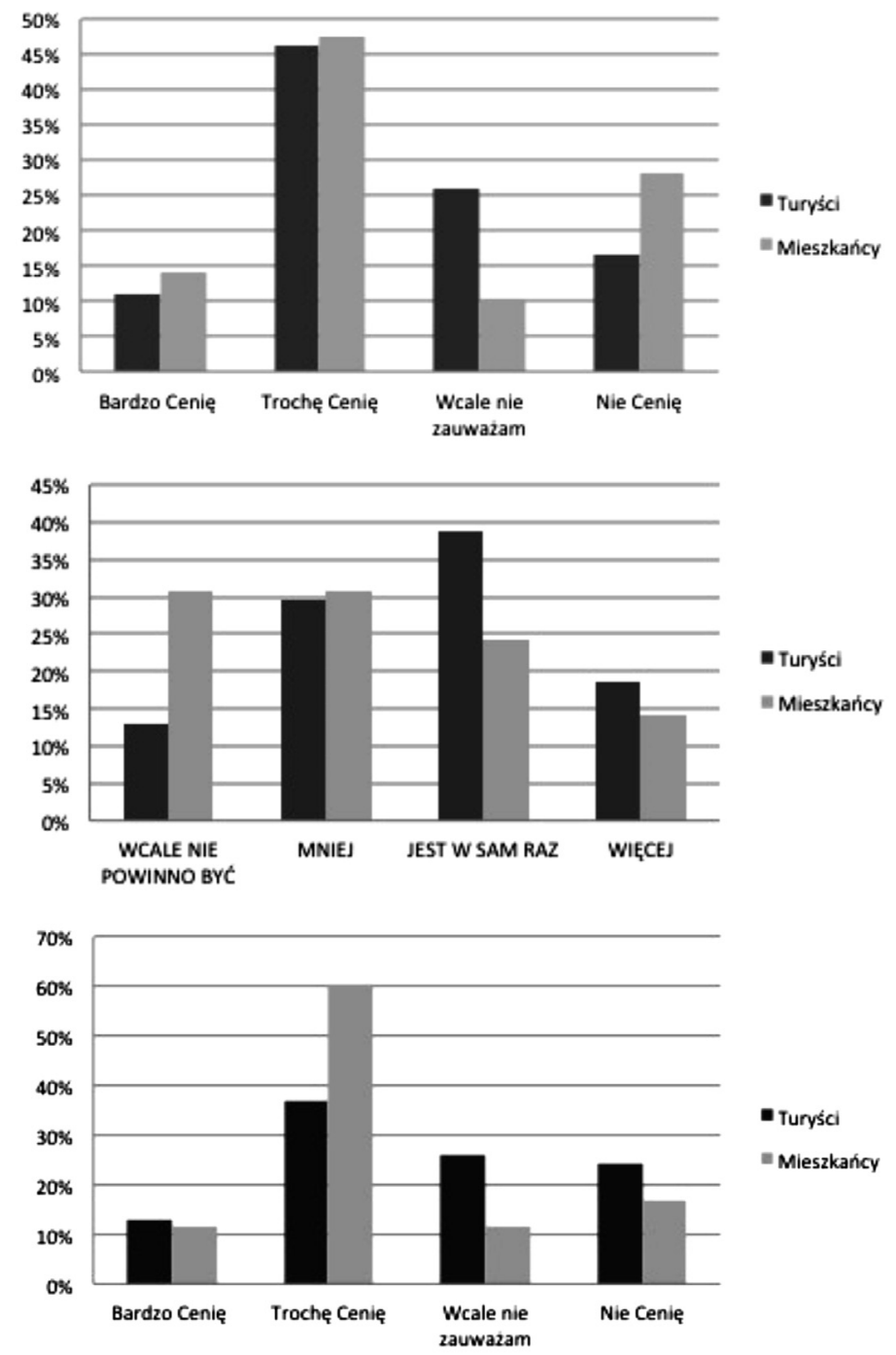

przeciw dominującym w przestrzeni ulicy reklamom i banerom. Obostrzenia dotyczące ich liczby i wielkości były ważnymi postulatami mieszkańców i turystów.

Wartość Krupówek ze względu na ich aspekt gospodarczy była oceniana przez obie grupy respondentów w podobny sposób. Mieszkańcy miasta silniej podkreślali ich wagę handlowego i usługowego centrum miasta, natomiast turyści, bardziej niż mieszkańcy cenili handel „z ręki do ręki”.

\section{WNIOSKI}

Krupówki odgrywają znaczącą rolę w Zakopanem - to główna arteria piesza, centrum handlowe, wizytówka miasta. Je układ i estetyka są niezwykle ważne. Mieszkańcy rozumieja i doceniają potencjat ekonomiczny ulicy, tak samo jak i odwiedzający ją turyści, którzy postrzegają ją jako obowiązkowy punkt wizyty w Zakopanem.

Miasto jest wyjątkowe w porównaniu do innych miast europejskich, dzięki występowaniu endemicznego, wernakularnego budownictwa, silnej kultury regionalnej i tradycji, ale także ich przekształceniu i uwspółcześnieniu dokonanemu dzięki stylowi zakopiańskiemu. Cechy te sprawiaja, że Zakopane jest
11. 4. Ocena Krupówek pod katem atrakcyinej scenerii, wi-
doków, zapachów i dźwieków. Żódto: Ankieta włtasna

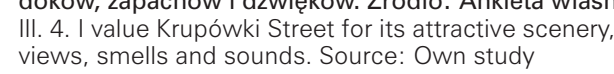

11. 5. Poziom akceptacji architektury wspó́tczesnej na KruIII. 5 . Level of acceptance of the presence of contemporary
architecture in the Krupówki Street Source: Own study

II. 6. Ocena Krupówek pod katem ekon
ści dla miasta. Zródto: Ankieta wtasna 1. 6. The value Krupónwi for its economic benefits like
tourism, trade and other commercial activities Source: tourism, trade
Own study

\section{CONCLUSIONS}

Krupówki Street plays a significant role in Zakothetics are critically important - it's the main walking street, commerce centre and the highlight of the city. Its arrangement and aesthetics are highly important.

Residents understand and appreciate the eco作 walking.

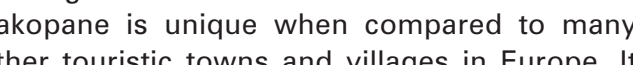
offers not only traditional highland architecture, but also integrates an early modernist heritage represented in forms based on vernacular build ing traditions. This makes Zakopane a spatial and architectural phenomenon and trademark of Polish culture. The growth of tourism and business

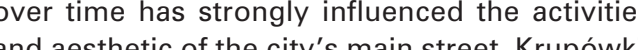
Those changes impacted the shape of the street in a negative way, which was observed both by Whe we can assume that the fenomenem przestrzenno-architektonicznym i znakiem rozpularnym miejscem dla turystów krajowych i zagranicznych. To właśnie rozwój turystyki i biznesu z czasem silnie wpłyneły na obraz i estetykę głównej ulicy miasta - Krupówek. Zmiany te, z czasem, zaczęły negatywnie kształtować jej odbió wizualny, zarówno przez odwiedzajacych, jak i mieszkańców. Można przyjać że ulica zawsze bedzie reagować na dynamike przyszłych zmian. Respondenci doceniag przestrzeń publicz-

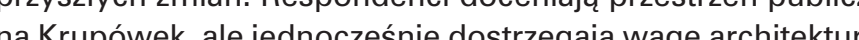
regionaj w krajobrazie tej ulicy. Jest to oczy arte, pokt waz mieszkn cy cenia sobie Kuṕ́nki i ch role w ochronie

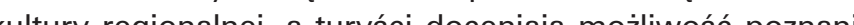

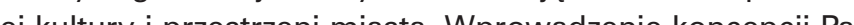
ku Kulturego, wdrozenie now ch zasad i przepisow w celu ku Kuluranego, wdoz i i nowych zas i przepisów w celu ukierunkowania rozwoju i zmian przestrzennych na Krupowkach pownno zaowecowac oczekiwanymi rezultatami. Po dwóch latach funkejonowania Parku Kulturowego można podjac colejne badania, ktore ujawnilyby zakres wprowadzonych zmian i stopien ich akceptacjl. Uzyskane wyniki pomogłyby stworzyć nową platformę do dyskusji nad sposobam poprawy atrakcyjnosci i walorów estetycznych Krupówe w najbliższych latach.

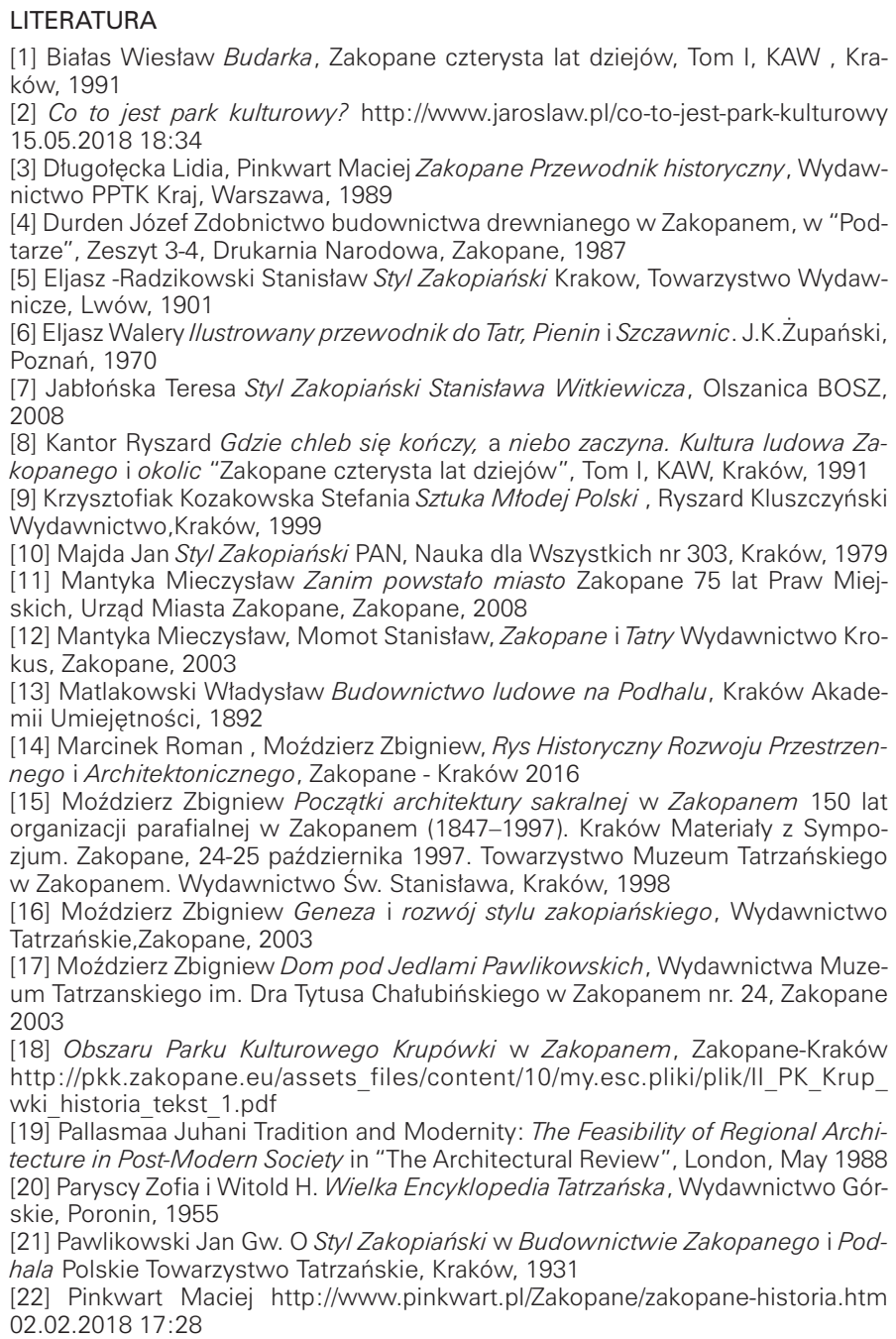

streetscape will always react to the dynamics of the fulure changes. The survey responders appreciate (time hey understand the importance of regional archThis is evid

Street and its rocause locals value Krupówk while tourists appreciate the possibility of learning about the local culture and city space.

The introduction of the 'Cultural Park' concept to guide development and spatial change in Krupów Street should be followed by a survey two years

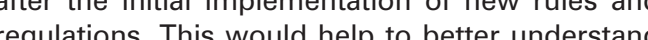
the acceptance of the changes and in the future enables the discussion on future ways of improving the attractiveness and the aesthetic value of the street for the city users.

BIBLIOGRAPHY

, Kialas W., Budarka, Zakopane czterysta lat dziejów, Tom 2] Co to jest park kultur

Wh? http://www.jaroslaw.pl/co-to-

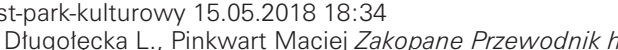
storyczny, Wydawnictwo PPTK Kraj, Warszaawa, 1989

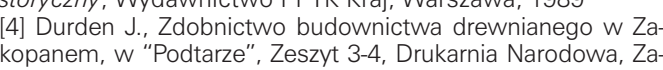
kopane, 1987 [5] Eljasz-Radzikowski S., Styl Zakopiański Krakow, Towarzy
stwo Wydawnicze, Lwów, 1901 stwo Wydawnicze, Lwów, 1901 [6] Eljasz W., /lustrowany przewodnik do Tatr, Pienin i Szczaw-

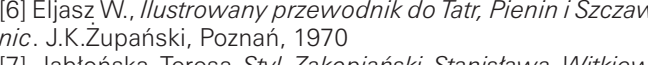
(7) Jabtońnka Teresa Styl Zakopiański Stanistawa Witkiewi-

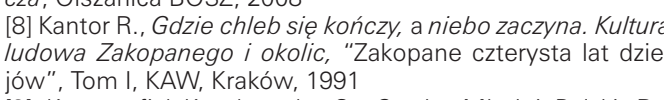
[9] Krzystoffiak-Korakowska S., Sztuka Mtodej Polski, Ry

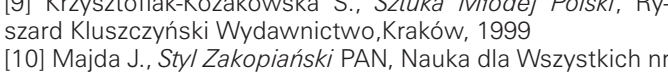
1101 Majda J., Sty/ Z
303, Kraków, 1979 [11] Mantyka M. Zanim powstato miasto Zakopane 75 lat
Praw Miejskich, Urzad Miasta Zakopane, Zakopane, 2008 dawnictwo Krokus, Zakopane, 2003, Zakopane I Tatry Wy[13] Matlakowski W., Budownictwo /udowe na Podhalu, Kra-
ków Akademii Umiejetności, 1892 [14] Marcinek R., Mózdzierr Zbignniew, Rys Historyczny Rozwoju Przestrzennego i Architektonicznego, Zakopane-Kra
ków 2016 ków 2016 panem 150 lat organizacaji parafiialnej w Zakopanem (1841997). Kraków Materiały z Sympozjum. Zakopane, $24-25$
października 1997. Towarzystwo Muzeum Tatrzańskiego w Zakopanem. Wydawnictwo Sw. Stanistawa, Kraków, 1998
[16] Moździerz Z.. Geneza i rozwó sty/u zakopianskiego, Wy(116] Moździerz Z., Geneza i rozwój sty/u zwo
dawnictwo Tatrzańskie,Zakopane, 2003

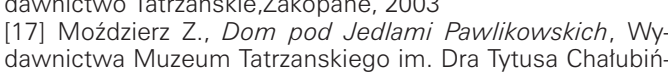
dawnictwa Muzeum Tatrzanskiego im. Dra Tytusa Chatub
skiego w Zakopanem nr. 24, Zakopane 2003 [18] Obszaru Parku Kulturowego Krupówki w Zakopanem

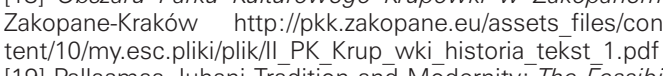
19) Pallasmaa Juhani Tradition and Modernity: Tiet Feasib-
lity of Regional Architecture in Post-Modern Society in "The Architectural Review", London, May 1988
[20] Paryscy Z., Witold H., Wielka Encyklopedia Tatrzańska. Wydawnictwo Górskie, Poronin, 1955 .

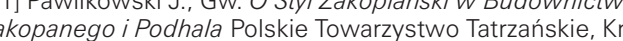
[22] Pinkwart M., http:///Www.pinkwart.pl/Zakopane/zakopa-
ne-historia.htm 02.02.2018 17 : 28 23] Raczka J. W. Walka o Polsk

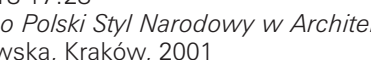
[24] Rzygocinska-Tyżuk B., Fenomenn ulicy gtównej jako "Ser-
ca Miasta" - Wybrane przyktady, Czasopismo Techniczne Politechniki Krakowskiej" 2008 
23] Raczka Jan Władysław Walka o Polski Styl Narodowy w Architekturze, Politechnika Krakowska, Kraków, 2001

[24] Rzygocińska - Tyżuk Barbara Fenomen ulicy głównej jako "Serca Mia sta"- Wybrane przykłady , "Czasopismo Techniczne Politechniki Krakowskiej” 2008

[25] Sosnowska Joanna M. Wystawa Paryska 1925, Materiały z sesji naukowej Instytutu Sztuki PAN, Warszawa, 16-17 listopada 2005 roku, Instytut Sztuki Polskiej Akademii Nauk, Warszawa, 2007

[26] Skowrońska Małgorzata Architektura drewniana Gminy Czarny Dunajec Wydawnictwo Artcards Czarny Dunajec | Chochołów, 2014

[27] Szafer Przemysław Architektura pasterska "Architektura” R. 32 [33]: nr 9/10 1979

[28] Tarnowski Józef Styl alpejski w Środkowej Europie i polska kontrakcja wobec niego - styl zakopiański. „Estetyka i Krytyka” nr 2 (25), Wydawnictwo Uniwersytetu Jagielońskiego, Kraków, 2012

29] Tłoczek Ignacy Dom mieszkalny na polskiej wsi, PWN, Warszawa, 1985

[30] Tondos Barbara, Styl Zakopianski i Zakopiańszczyzna, Zakład Narodowy im. Ossolińskich Wrocław 2009

[31] Witkiewicz Stanisław Styl Zakopiański, Zeszyt II- Ciesielstwo Wydawnictwo H. Altenberga, Lwów, 1911,

[32] Witkiewicz Stanisław Styl zakopiański. Zeszyt I: Pokój jadalny, Wydawnictwo H. Altenberga, Lwów, 1904

[33] Żychoń Stefan Rozwój Przestrzenny i Budownictwo, Zakopane czterysta lat dziejów, Tom I, KAW, Kraków, 1991

[34] Żychoń Stefan Zagospodarowanie Równi Krupowej i Rewaloryzacja Centrum Zakopanego, „Podtatrze”, Zima, Urząd Miasta Zakopane, 1977
25] Sosnowska J. M., Wystawa Paryska 1925, Materiały z sesji naukowej Instytutu Sztuki PAN, Warszawa, 16-17 listopada 2005 roku, Instytut Sztuki Polskiej Akademii Nauk, Warszawa, 2007

[26] Skowrońska Małgorzata Architektura drewniana Gminy Czarny Dunajec Wydawnictwo Artcards Czarny DunajecChochołów, 2014

[27] Szafer Przemysław Architektura pasterska "Architektura" R. 32 [33]: nr 9/10, 1979

[28] Tarnowski Józef Styl alpejski w Środkowej Europie polska kontrakcja wobec niego - styl zakopiański. „Estetyka i Krytyka" nr 2 (25), Wydawnictwo Uniwersytetu Jagielońskiego, Kraków, 2012

[29] Tłoczek Ignacy Dom mieszkalny na polskiej wsi, PWN, Warszawa, 1985

[30] Tondos Barbara, Styl Zakopianski i Zakopiańszczyzna. Zakład Narodowy im. Ossolińskich, Wrocław 2009

[31] Witkiewicz Stanisław Styl Zakopiański, Zeszyt II - Ciesielstwo Wydawnictwo H. Altenberga, Lwów, 1911

[32] Witkiewicz Stanisław Styl zakopiański. Zeszyt I: Pokój jadalny Wydawnictwo H. Altenberga, Lwów, 1904

[33] Żychoń Stefan Rozwój Przestrzenny i Budownictwo, Zakopane czterysta lat dziejów, Tom I, KAW, Kraków, 1991

[34] Zychoń Stefan Zagospodarowanie Równi Krupowej i Rewaloryzacja Centrum Zakopanego, „Podtatrze”, Zima, Urząd Miasta Zakopane, 1977 